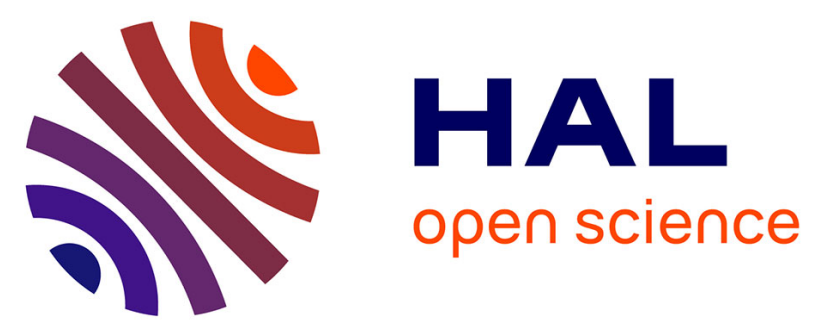

\title{
A framework for understanding climate change impacts on coral reef social-ecological systems
}

\author{
Joshua Eli Cinner, Morgan Stuart Pratchett, Nicholas Anthony James \\ Graham, Vanessa Messmer, Mariana Menezes Prata Bezerra Fuentes, Tracy \\ Ainsworth, Natalie Ban, Line Kolind Bay, Jessica Blythe, Delphine Dissard, et \\ al.
}

\section{To cite this version:}

Joshua Eli Cinner, Morgan Stuart Pratchett, Nicholas Anthony James Graham, Vanessa Messmer, Mariana Menezes Prata Bezerra Fuentes, et al.. A framework for understanding climate change impacts on coral reef social-ecological systems. Regional Environmental Change, 2016, 16 (4), pp.11331146. 10.1007/s10113-015-0832-z . hal-01306704

\section{HAL Id: hal-01306704 https://hal.univ-reunion.fr/hal-01306704}

Submitted on 26 Apr 2016

HAL is a multi-disciplinary open access archive for the deposit and dissemination of scientific research documents, whether they are published or not. The documents may come from teaching and research institutions in France or abroad, or from public or private research centers.
L'archive ouverte pluridisciplinaire HAL, est destinée au dépôt et à la diffusion de documents scientifiques de niveau recherche, publiés ou non, émanant des établissements d'enseignement et de recherche français ou étrangers, des laboratoires publics ou privés. 


\title{
A framework for understanding climate change impacts on coral reef social-ecological systems
}

\author{
Joshua Eli Cinner ${ }^{1} \cdot$ Morgan Stuart Pratchett $^{1} \cdot$ Nicholas Anthony James Graham $^{1}$ • \\ Vanessa Messmer $^{1}$ - Mariana Menezes Prata Bezerra Fuentes ${ }^{1,2} \cdot$ Tracy Ainsworth $^{1}$. \\ Natalie Ban ${ }^{1,3} \cdot$ Line Kolind Bay1,4 $\cdot$ Jessica Blythe ${ }^{1,5}$ • Delphine Dissard ${ }^{1,6}$ • \\ Simon Dunn ${ }^{7,8} \cdot$ Louisa Evans $^{1,9} \cdot$ Michael Fabinyi ${ }^{1} \cdot$ Pedro Fidelman $^{1,10}$. \\ Joana Figueiredo $^{1,11}$ - Ashley John Frisch ${ }^{1}$ Christopher John Fulton ${ }^{12}$. \\ Christina Chemtai Hicks ${ }^{1,13}$. Vimoksalehi Lukoschek ${ }^{1}$. Jennie Mallela ${ }^{14,15}$. \\ Aurelie Moya $^{1} \cdot$ Lucie Penin $^{1,16} \cdot$ Jodie Lynn Rummer $^{1} \cdot$ Stefan Walker $^{1}$. \\ David Hall Williamson ${ }^{1}$
}

\begin{abstract}
Corals and coral-associated species are highly vulnerable to the emerging effects of global climate change. The widespread degradation of coral reefs, which will be accelerated by climate change, jeopardizes the goods and services that tropical nations derive from reef ecosystems. However, climate change impacts to reef social-ecological systems can also be bi-directional. For example, some climate impacts, such as storms and sea level rise, can directly impact societies, with repercussions
\end{abstract}

Joshua Eli Cinner

Joshua.cinner@jcu.edu.au

$1 \quad$ ARC Centre of Excellence for Coral Reef Studies, James Cook University, Townsville, QLD 4811, Australia

2 Earth, Ocean and Atmospheric Science, Florida State University, Tallahassee, FL 32306, USA

3 School of Environmental Studies, University of Victoria, Victoria, BC, Canada

4 Australian Institute of Marine Science, PMB 3, Townsville, QLD 4810, Australia

5 WorldFish, Honiara, Solomon Islands

6 IRD-Sorbonne Universités (UPMC, Univ Paris 06)-CNRSMNHN, LOCEAN Laboratory, IRD France-Nord, 32, Avenue Henri Varagnat, 93143 Bondy, France

7 ARC Centre of Excellence for Coral Reef Studies, University of Queensland, St Lucia, Brisbane, QLD 4072, Australia

8 School of Biological Sciences, University of Queensland, St Lucia, Brisbane, QLD 4072, Australia

9 Geography, College of Life and Environmental Sciences, University of Exeter, Exeter, UK for how they interact with the environment. This study identifies the multiple impact pathways within coral reef social-ecological systems arising from four key climatic drivers: increased sea surface temperature, severe tropical storms, sea level rise and ocean acidification. We develop a novel framework for investigating climate change impacts in social-ecological systems, which helps to highlight the diverse impacts that must be considered in order to develop a more complete understanding of the impacts of climate change, as well as developing appropriate management

10 Sustainability Research Centre, University of the Sunshine Coast, Maroochydore, QLD 4558, Australia

11 Oceanographic Center, Nova Southeastern University, 8000 N Ocean Drive, Dania Beach, FL 33004, USA

12 ARC Centre of Excellence for Coral Reef Studies, Research School of Biology, The Australian National University, Canberra, ACT 2601, Australia

13 Center for Ocean Solutions, Stanford Woods Institute for the Environment, Stanford University, Monterey, CA 93940, USA

14 ARC Centre of Excellence for Coral Reef Studies, Research School of Earth Sciences, The Australian National University, Canberra, ACT 0200, Australia

15 Research School of Biology, The Australian National University, Canberra, ACT 0200, Australia

16 UMR 9220 UR CNRS IRD ENTROPIE - Ecologie mariNe TROpicale des océans Pacifique et IndiEn, University of Reunion Island, Saint-Denis, France 
actions to mitigate climate change impacts on coral reef and people.

Keywords Social-ecological · Coral reef - Climate change Multiple impacts

\section{Introduction}

Climate change has rapidly emerged as one of the major long-term threats to coral reefs (e.g. Hoegh-Guldberg et al. 2007; Hughes et al. 2003; McClanahan and Cinner 2012). Numerous studies have quantified the ecological impacts of disturbance on coral reefs and examined how projected increases in ocean temperature, acidity and the increasing frequency of high-intensity storm events will impact coral communities (De'ath et al. 2012), and reef-associated organisms, principally fishes (e.g. Wilson et al. 2006). These studies are important in understanding how climate change will impact on the sustainability and productivity of coral reef fisheries (Bell et al. 2013; Burrows et al. 2014; Cheung et al. 2010). Aside from fisheries impacts, little is known about how climate change may impact coral reefdependent human societies and the major drivers and pathways through which this may operate (Carpenter et al. 2009; Daw et al. 2009).

Millions of people, primarily from developing countries, are heavily dependent on the goods and services provided by coral reefs (Teh et al. 2013). These goods and services include fisheries, tourism, coastal protection, habitat provision for valuable species and cultural values (Hicks 2011). An emerging literature has begun to explore the vulnerability of coastal societies to climate change impacts on marine fisheries and ecosystem health (Bell et al. 2013; Béné et al. 2012; Marshall and Marshall 2012). To date, most of these studies tend to take a uni-directional view of impact pathways (i.e. climate change impacts key aspects of the ecosystem, which in turn impacts society) (e.g. Allison et al. 2009; Cinner et al. 2012; MacNeil et al. 2010). However, climate change may not only interrupt the flow of goods and services to society, but may also alter how people interact with reefs, creating potential pathways from society to ecosystems (Butler and Oluoch-Kosura 2006; Cinner et al. 2011; Daw et al. 2009). Critically, coral reefs are linked social-ecological systems (Kittinger et al. 2012; Walker and Meyers 2004), meaning that the changes in the ecological domain may influence social dynamics and vice versa.

A major impediment to understanding the impacts that climate change will have on human societies dependent on coral reefs, and vice versa, is the limited consideration of multiple pathways through which impacts can manifest, especially indirect and bi-directional linkages among distinct components of social-ecological systems. Frameworks exist that reflect the interdependent nature of human-environment systems (e.g. Kittinger et al. 2012), but the majority of research on climate change and coral reefs is focused on unidirectional flow of both benefits and impacts from environment to people (e.g. Bell et al. 2013). Here, we contribute to expanding this emerging field of research in two important ways. First, we explicitly consider the multitude of pathways through which select climate drivers (e.g. increasing temperatures) will impact coral reefs and reef-dependent societies, exploring the existence of well-supported or hypothesized linkages across relevant components of the social-ecological system. Secondly, we also highlight key instances when the impact pathways are expected to be bi-directional (e.g. also flow from people to ecosystems). Our review of impact pathways focuses on four distinct climate drivers: (1) increasing sea surface temperature; (2) increasing frequency and/or intensity of storms; (3) sea level rise; and (4) ocean acidification. This is not to say other environmental changes (e.g. depth stratification and declines in vertical mixing, shifts in the position and strength of ocean currents, and changes in rainfall and freshwater input) will not have equally important or even greater impacts on coral reefs and reef-dependent societies. However, it is not our intention to comprehensively assess the multitude of impacts arising from sustained and ongoing climate change. Rather, we present key exemplars to provide a focus for understanding the existence of multiple impact pathways.

Potential impacts of climate change on coral reef ecosystems have been extensively reviewed (e.g. HoeghGuldberg et al. 2007; MacNeil et al. 2010; Pratchett et al. 2008; Wilson et al. 2006), as have (to a lesser extent) the flow-on effects to reef-dependent and coastal societies (e.g. Allison et al. 2009; Badjeck et al. 2010; Burke et al. 2011; Cinner et al. 2012; McClanahan and Cinner 2012). The novelty of this study is not only to understand impacts of climate change on coral reefs and reef-dependent societies, but explicitly recognize that societal responses may in turn impact on natural resources and the environment. Our approach was centred around five key components of the social-ecological system: (1) Environment, which includes aspects of habitat availability, water chemistry, primary productivity and the structural complexity of the benthic habitat; (2) Population dynamics of exploited or ecologically important organisms, including dispersal and intrinsic growth rates; (3) Resource availability, which includes abundance, richness, distribution and behaviour; (4) Fisheries, which includes aspects of yield, fishing effort and variability; and (5) Societal well-being, which includes livelihoods, human health and safety, infrastructure and cultural 
Fig. 1 Conceptual figure showing: a the five key components of the socialecological system (developed based on expert opinion) used to guide consideration of multiple links and impact pathways, and the specific mechanistic bases of potential impacts considered for each component, and: be different impact pathways linking specific drivers to mechanisms of impact. Sea surface temperature (b) mainly affects environmental conditions like structural complexity availability of habitat and primary production. Storms (c) affect processes like settlement, and thereby availability of resources, fishing effort in stormy seas and fisher safety. Sea level rise (d) has significant direct impacts on societal well-being through coastal erosion and inundation, which could motivate fishers to exit the fishery leading to positive feedbacks on resource abundance, richness and ecological function. Ocean acidification (e) has weaker impacts through environmental conditions and processes relative to the other drivers by the end of the century, but acts as an important cumulative impact on, for example, habitat complexity and reproduction. Red arrows represent a potentially negative impact. Green arrows represent a potentially positive influence.

The width of the arrows reflects the strength of the pathway, with dotted arrows representing weaker and less certain pathways, and thick arrows representing strong pathways with considerable certainty (color figure online) (a)
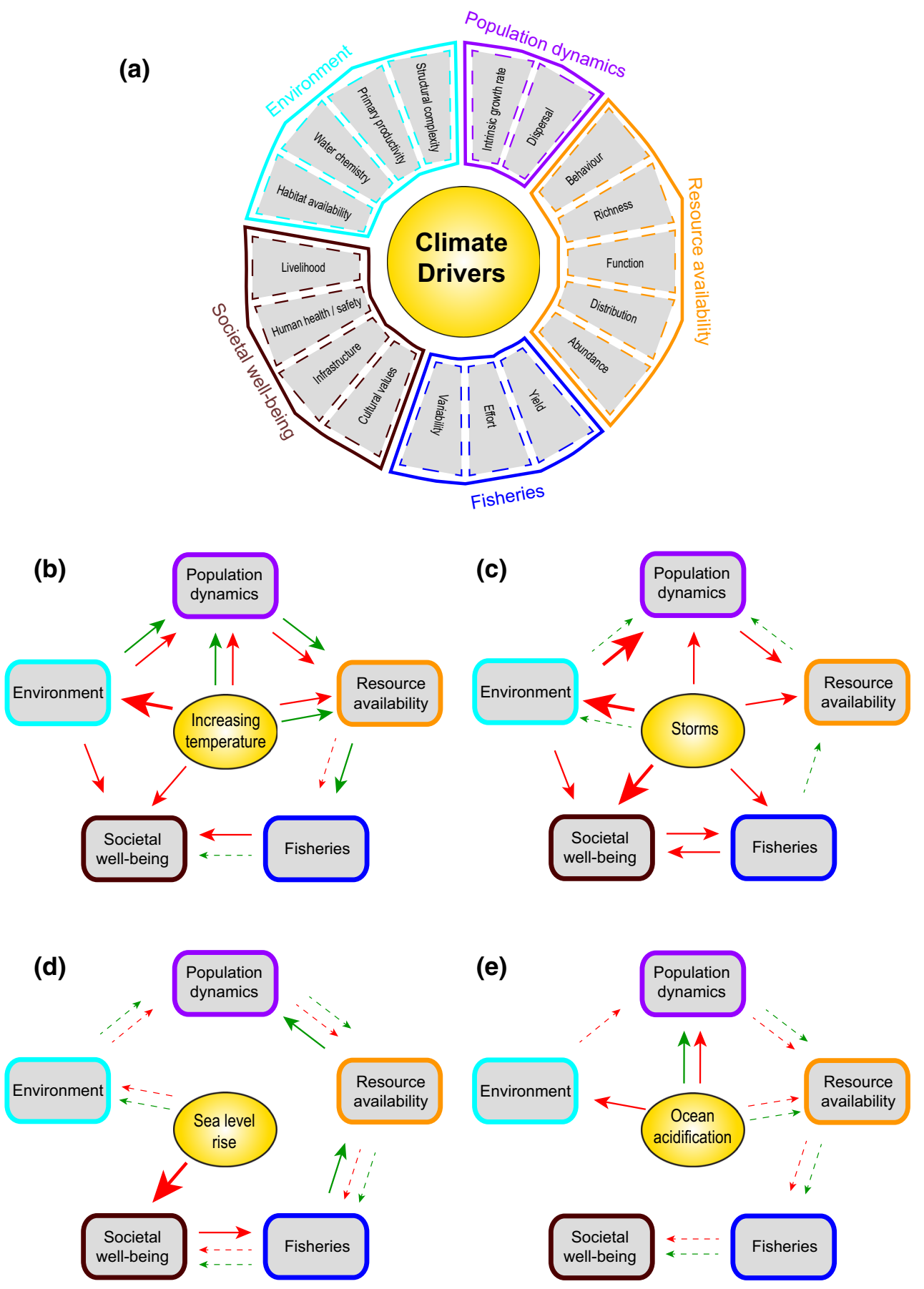

values (Fig. 1a). These five components of the socialecological system were developed based on expert opinion of the authors and are intended to be representative rather than comprehensive, providing an explicit focus for analyses of multiple links and impact pathways. For each of these components, we reviewed published studies to establish whether there are likely or documented impacts arising from each of the distinct climatic drivers (increasing temperature, storms, sea level rise and ocean acidification). Moreover, we reviewed evidence of bi- directional linkages between each successive pair of the five social-ecological components, thereby highlighting the multiple impact pathways through which climate change will impact coral reef social-ecological systems. Exploration of multiple links and impact pathways among the major social-ecological components was necessarily constrained to specific mechanisms by which impacts may become manifest, e.g. changes in the overall yield, effort or variability in yields for fisheries (Fig. 1a). These subcomponents are broadly reflective of anticipated and well- 
studied impacts, but are certainly not intended to capture the comprehensive range of potential impacts.

\section{Sea surface temperatures (Fig. 1b)}

Increasing atmospheric and ocean temperatures is the most pervasive effect of increasing concentrations of atmospheric greenhouse gases (Hartmann et al. 2013) with direct biological impacts (e.g. Hughes 2000; Walther et al. 2002). Sea surface temperature (SST) of the tropical oceans has warmed $\sim 0.08{ }^{\circ} \mathrm{C} /$ decade over the period 1950-2011 (Lough 2012). Under relatively optimistic future greenhouse gas emission reductions, projected increases in SST range from $\sim 0.5$ to $1.5{ }^{\circ} \mathrm{C}$ by mid-century (Kirtman et al. 2013) and from $\sim 0.7$ to $2.5^{\circ} \mathrm{C}$ by the end of the twentyfirst century (Collins et al. 2013). Significant increases in thermal fluctuations, as well as higher frequency and duration of hot temperature extremes, are also projected (Collins et al. 2013; Walther et al. 2002).

\section{Key impact pathways}

The most apparent impact of ocean warming on coral reef ecosystems, to date, has been the recurrence of mass bleaching events (e.g. Donner et al. 2005) where ambient temperatures exceed the critical thermal limits of many coral species (Donner 2009). These bleaching events reduce coral fitness (Howells et al. 2013) and may cause widespread coral mortality (Eakin et al. 2010; McClanahan 2004). In 1998, for example, up to $90 \%$ of habitat-forming corals were lost in many parts of the Indian Ocean (Graham et al. 2006). Extensive coral mortality results in large-scale changes to the reef environment, such as habitat loss and a collapse of the structural complexity of coral reef architecture (large red arrow between sea surface temperature and environment in Fig. 1b; Graham et al. 2006). In the absence of sufficient herbivores, these changes can further alter the environment through phase shifts to algal-dominated states (Hughes et al. 2010). Directional shifts in the structure of coral reef habitats further impact the population and community dynamics of reef-associated organisms, generally leading to declines in abundance and diversity of fish (e.g. Pratchett et al. 2011; Wilson et al. 2006), and other associated organisms (Stella et al. 2011).

Aside from climate-induced changes in habitat structure, ocean warming can also directly impact population dynamics such as the physiology, behaviour and fitness of reef-associated organisms. Tropical species, such as reef fishes tend to have very narrow thermal tolerances and also live very close to their upper thermal limits (e.g. Dillon et al. 2010; Donelson et al. 2010; Rummer et al. 2014; Tewksbury et al. 2008), making them extremely vulnerable to sustained increases in baseline temperature, as well as acute fluctuations in maximum temperatures (Munday et al. 2008). In responding to sustained and ongoing temperature increases, coral reef organisms may move to higher latitudes or increasing depths (Cheung et al. 2009). However, coral reef organisms (both fish and invertebrates) exposed to high temperatures may experience accelerated development (Figueiredo et al. 2014; Heyward and Negri 2010; McLeod et al. 2013; O'Connor et al. 2007), increased growth rates (e.g. Fulton et al. 2014; Munday et al. 2008), reduced body size (Daufresne et al. 2009), lower fecundity (McClanahan et al. 2009) and increased metabolic rates (Rummer et al. 2014). These changes may lead to reduced abundance and fitness of affected populations, as well as reduced connectivity among populations.

The sensitivity of reef-associated organisms to increasing temperatures and extreme hot weather events varies greatly, depending on specific thermal limits and local thermal history (Munday et al. 2012). Importantly, there are likely to be winners and losers (Graham et al. 2014; Pratchett et al. 2011). For example, not all reef fish species decline in abundance (at least in the short term) following bleaching-induced changes to reef habitats. Some species exhibit rapid and pronounced increases in abundance after bleaching (green arrows from environment, through population dynamics, and resource availability in Fig. 1b; Cinner et al. 2013; Pratchett et al. 2011). It is likely that some fishers will be able to take advantage of these changes to receive at least short-term increases in fish catch. For example, fishing gears that target herbivorous fishes may see short-term catch increases after a coral bleaching event (Cinner et al. 2013), but these may not carry through to an increase in income for the wider fishery (McClanahan et al. 2008). In the longer-term, temperatureinduced changes to benthic habitat complexity and availability are expected to erode reef productivity and ultimately lead to reductions in fishery yields and fishers' livelihoods (Barange et al. 2014; Bell et al. 2013; Graham et al. 2007; Williamson et al. 2014). However, the empirical evidence of climate-induced changes upon resource availability, the fishery and associated societal well-being have yet to be conclusively demonstrated (indicated by dotted arrows between fishery and societal wellbeing in Fig. 1b; MacNeil et al. 2010). Importantly, this does not mean that climate change cannot impact societal well-being through this pathway. These changes are complex and difficult to detect (given the SST changes to date), and there is a paucity of research on reef fisheries attempting to disentangle these causal links (e.g. how temperature-induced changes to dispersal may impact the distribution and abundance of key target species).

The direct impacts of increased SST in tropical oceans can also affect human well-being and human health (red arrow directly from sea surface temperature to societal 
wellbeing in Fig. 1b). For example, increasing SST can result in increased phytoplankton blooms that are related to incidents of shellfish poisoning (Allison et al. 2009; Baschieri and Kovats 2010), toxic dinoflagellates such as Gambierdiscus spp. associated with ciguatera fish poisoning (Chateau-Degat et al. 2005; Tester et al. 2010), and conditions conducive to cholera outbreaks because the Vibrio cholerae bacterium thrives in warmer waters (Ceccarelli and Colwell 2014; Lipp et al. 2002). The socioeconomic impacts of human health-related incidents due to microbial outbreaks include health-related costs, loss of labour productivity, loss of a food source, loss of reef fish sales in both local and international markets, and changes to the social, cultural and traditional characteristics of fishing communities (Rongo and van Woesik 2012). These impacts affect the well-being of people directly, but also indirectly through a loss of tourism (Westmacott et al. 2000). In particular, the potential increase in production of harmful viruses and biotoxins could have severe implications for societies unprepared for their increased prevalence and range expansions (Hallegraeff 2010).

\section{Severe tropical storms (Fig. 1c)}

The effects of climate change (specifically, ocean warming) on the frequency and severity of tropical storms (e.g. cyclones and hurricanes) are complex (Haig et al. 2014; Klotzbach 2006; Landsea et al. 2006; Webster et al. 2005). Intuitively, increasing SST will increase energy and intensity of severe tropical storms, and consistent with this link, several recent analyses suggest that extreme wave heights have been increasing over the last decades (Elsner et al. 2008; Hoyos et al. 2006; Young et al. 2011). However, fluctuations in the frequency and intensity of tropical cyclones make it very difficult to detect clear long-term trends, especially during the period that there have been unequivocal increases in atmospheric temperature due to anthropogenic forcing (Knutson et al. 2010). Empirical data point to recent declines in the incidence of high-intensity tropical storms (Callaghan and Power 2011), yet the global incidence of high-intensity tropical storms (e.g. category 5 cyclones) is expected to increase with ocean warming (Knutson et al. 2010).

\section{Key impact pathways}

Severe storms can cause extensive physical damage to coral reef environments (thick red arrow between storms and environment in Fig. 1c; De'ath et al. 2012). For example, physical disturbance during intense storms fractures carbonate reef foundations (McAdoo et al. 2011; Nott and Hayne 2001), reducing live coral cover and structural complexity by 80-100\% (Harmelin-Vivien 1994). This physical damage also redistributes sediment and rubble, which increases water turbidity and can smother some reefs (McAdoo et al. 2011; Scoffin 1993; Vanwoesik et al. 1991; Woodley 1980). Storm impacts are correlated to frequency and/or intensity of events and, in general, negatively affect coral reef social-ecological systems. Yet, storm events can also facilitate windows of opportunity for renewal within ecological systems. For instance, intense storms have scoured algal-covered reefs, providing opportunities for corals to recruit (indicated by green arrow between storms and environment in Fig. 1c; Graham and Nash 2013).

The physical disturbance caused during and after storms also impacts population dynamics such as recruitment, settlement and survival of coral and fish larvae (Lassig 1983), which, in turn, reduce the abundance and diversity of species, with potential impacts to the fishery. Several studies have attempted to quantify changes to fish abundance following a storm, with inconsistent results. For example, Fenner (1991) found that fish populations were largely unaffected over 22 months following a severe storm in Mexico. Lassig (1983) found little effect on adult fishes, but high juvenile mortality and re-distribution of sub-adult fishes after 27 months post-storm on the Great Barrier Reef, Australia. Further, in a longer-term study, Halford et al. (2004) found that of 26 fish species analysed on the GBR, 23 decreased in abundance post-storm(s), with all but two species recovering to pre-disturbance levels after 10 years.

Storms can also directly affect aspects of resource availability (Fig. 1c). For instance, some fish species change their behaviour and movement patterns in storms (Heupel et al. 2003; Kawabata et al. 2010; Locascio and Mann 2005). These changes can in turn influence the catchability of fishes and/or reduce their availability to fishers, impacting fishery yields, incomes and adding to the inherent variability in a fishery (Tobin et al. 2010). For example, Marshall and Marshall (2012) reported reduced catches nine months after category 5 Cyclone Yasi on the Great Barrier Reef. Storms therefore have a mix of shortand long-term effects on resource availability. Where major structural changes occur on the reef environment, long-term effects are highly likely.

Severe storms can also directly impact social well-being, imposing significant risk to infrastructure, human health and safety. For instance, extreme surface waves produced by typhoons/cyclones can propel large parts of carbonate reef (e.g. $14 \mathrm{~m}$ waves moving 235-tonne boulders, Goto et al. 2011) to cause major damage to landing sites, boats and gear, with knock on effects to coastal livelihoods and incomes. In Antigua and Barbuda, damage and loss of fishing fleet assets resulted in an estimated decrease of $24 \%$ in gross revenues (Mahon 2002). Damage to fishery infrastructure and reduced fleet capacity 
could also have flow-on effects that result in increased resource availability and population dynamics (indicated by green dotted arrows between fishery, resource availability and population dynamics in Fig. 1c; Baird et al. 2005). Damage to reefs from storms can also directly affect societal well-being because tourists may stop visiting certain reefs that have experienced severe storm damage, with flow-on effects to tourism-dependent livelihoods. Severe direct effects on aspects of societal well-being such as health, safety and the loss of life following extreme events can further cascade into chronic impacts on other household and community aspects of life (Blythe et al. 2013; Westlund et al. 2007).

In addition to direct mechanical damage, storms can lead to increases in rainfall, severe flooding, runoff and surface currents. These in turn can cause elevated catchment runoff (e.g. freshwater, sediment, nutrients and pollutants), enhanced coastal erosion and increases in marine sediment re-suspension which all result in declining coral and fish health (Cheal et al. 2013; Fabricius and Wolanski 2000; Goatley and Bellwood 2012; Mallela et al. 2007; Wenger et al. 2012, 2013, 2014), as well as potential habitat loss. Storm surges can directly impact societal wellbeing by lowering the availability and quality of limited freshwater sources of atoll nations (Bridges and McClatchey 2009). The microbial community in both the water column and surface biofilms is also altered by runoff and sedimentation, and while these shifts may be bioindicators of change (Witt et al. 2012), they are also associated with a shift towards greater organism disease. These community shifts towards pathogenic microbial communities is linked to the emergence of disease in vertebrate and invertebrate hosts (Sandin 2009; Thurber et al. 2012) and also within human populations using reef resources (Burge et al. 2014). Negative feedbacks between run-off, ecosystem decline and human health will be further exacerbated in developing regions where wastewater treatment infrastructure is limited.

\section{Sea level rise (Fig. 1d)}

There is considerable uncertainty about the likely magnitude of sea level rise, in part due to the unpredictable nature and instability of key ice sheets. Sea level is currently rising at approximately $3.2 \mathrm{~mm}$ per year due to thermal expansion of the ocean and melting of land ice, and the rate of change is accelerating (Rhein et al. 2013). Continued melting of the polar ice sheets will increase sea level rise, by as much as $3-5 \mathrm{~m}$ by 2100 (Overpeck et al. 2006). Coral reef ecosystems are generally resilient to sea level fluctuations, and even rapid changes in the geological past (e.g. a 2- to 3-m jump with years to decades approximately 121,000 years ago) have had only minor impacts on the growth and development of reef assemblages (Blanchon et al. 2009). Increase in sea level does, however, pose a significant threat to the millions of people who inhabit coastal villages and cities (Overpeck et al. 2006).

\section{Key impact pathways}

Sea level rise is perhaps the most unique climate change driver in that it is not expected to have profound direct negative effect on coral reef environments because accretion rates of coral are generally sufficient to keep pace with sea level rise. In fact, coral reefs in some locations might benefit due to increased habitat availability (i.e. coral reefs growing upwards as coral recolonizes the tops of currently mature reefs, and as corals expand into areas currently too shallow for them to inhabit; dotted green arrows from sea level rise to environment in Fig. 1d). Humans may benefit from this increased habitat availability through increased primary productivity, resource availability, fishery yields and, ultimately, increased fisheries productivity. However, coral reef-associated species could be negatively affected by sea level rise if they depend on habitats that are not capable of vertical migration as the sea rises (e.g. coastal development may prevent mangrove forests or turtle nesting beaches from moving inland; dotted red arrows in Fig. 1d).

While there could be minor ecological benefits to coral reefs, sea level rise is expected to have direct negative impacts on societal well-being (thick red arrow in Fig. 1d). Rising seas, especially when combined with severe storm events, threaten coastal infrastructure. Damage to ports and docks could reduce fishing fleet capacity, creating negative impacts on livelihoods yet alleviating pressure on marine resources (red arrow between societal well-being and fishery, and slow on green arrows to resource availability and population dynamics in Fig. 1d; Adger et al. 2005). Many low-lying tropical islands are in peril, and whole nations may become uninhabitable, for example, atoll nations such as Kiribati (McCarthy et al. 2001). Climate change-induced migration has been linked to increased possibilities for violent conflict (e.g. in areas of in-migration) and is likely to have greater impacts upon poorer members of coastal societies (Reuveny 2007). While this form of migration, if planned strategically, also has potential benefits (e.g. income diversification) and can be viewed as an adaptive response to environmental conditions (Black et al. 2011), it is important to bear in mind that biophysical changes enter stratified social systems, meaning that impacts are experienced differentially due to class, castes, gender, profession, race, ethnicity, age and ability (Marino 2012). Sea level rise is likely to create variable social impacts in places like the Pacific where fishing strategies vary by cultural group, gender and habitat fished 
(coastal reef, lagoon and outer reef; Kronen and Vunisea 2009). The links between sea level rise, human migration and well-being are thus complex and context dependent (Black et al. 2011; Farbotko and Lazrus 2012).

\section{Ocean acidification (Fig. 1e)}

Increased atmospheric $\mathrm{CO}_{2}$ is readily dissolved into the world's oceans, leading to marked changes in seawater chemistry (most notably declines in $\mathrm{pH}$, carbonate ion concentrations and carbonate saturation state), commonly referred to as ocean acidification (Caldeira and Wickett 2003). Rapidly rising atmospheric partial pressure of carbon dioxide $\left(p \mathrm{CO}_{2}\right)$ over the last century has induced a lowering of oceanic $\mathrm{pH}$ by $\sim 0.1$ units (from $\sim 8.25$ to $\sim 8.14$, Orr et al. 2005). Estimates of future atmospheric $p \mathrm{CO}_{2}$ (Pörtner et al. 2014) suggest a further decrease of 0.3 $\mathrm{pH}$ units by the end of the century (Caldeira and Wickett 2003). These marked and sustained changes in seawater chemistry of oceanic waters (e.g. Doney et al. 2009) are raising concerns. However, seawater chemistry in nearshore environments (e.g. within the immediate vicinity of corals reefs) is highly variable, fluctuating over diurnal (due to respiration and photosynthesis of coral reef organisms), tidal and seasonal cycles, and daily extremes often exceed the projected levels of $\mathrm{pCO}_{2}$ and $\mathrm{pH}$ to occur by the end of the century in open ocean waters (Albright et al. 2013; Guadayol et al. 2014; Hofmann et al. 2011; Shaw et al. 2013).

\section{Key impact pathways}

A wide range of coral reef organisms, from calcifying algae through to large piscivorous fishes, are affected by exposure to extreme levels of $\mathrm{pCO}_{2}$ or reduced $\mathrm{pH}$ (De'ath et al. 2009; Munday et al. 2013; Pandolfi et al. 2011; Fig. 1e). For calcifying organisms, such as reef-building corals, the concern is that low levels of aragonite saturation will increase the energetic cost of calcification, thereby compromising skeletal growth and/or development (Doney et al. 2009). By 2050, sustained declines in aragonite saturation are expected to cause $10-50 \%$ reduction in calcification rates of key reef-building corals relative to preindustrial rates (Kleypas and Langdon 2006; Kleypas and Yates 2009; Langdon and Atkinson 2005). The decline in calcium carbonate production, coupled with an increase in calcium carbonate dissolution, may result in reduced cover of corals, coralline algae and other calcareous reef-building organisms, leading to marked declines in reef growth and topographic structure of reef habitats (red arrow between ocean acidification and environment in Fig. 1e). Although some coral species are able to internally buffer their $\mathrm{pH}$ (Dissard et al. 2012; McCulloch et al. 2012), a study on coral reefs exposed to volcanic $\mathrm{CO}_{2}$ seeps in $\mathrm{PNG}$ showed a loss of many coral species, which resulted in reduced coral diversity and a shift to corals of low structural complexity and calcification rates (Fabricius et al. 2011). A loss in structural complexity (e.g. Graham et al. 2006; Wilson et al. 2006) and coral diversity (e.g. Messmer et al. 2011) is expected to have negative impacts on fish productivity (dotted red arrows between environment, population dynamics, resource availability and fishery in Fig. 1e).

Early life history stages of coral and fishes are also at high risk from ocean acidification (red arrow between ocean acidification and population dynamics in Fig. 1e). Exposure to reduced $\mathrm{pH}$ has been shown to affect development and suppress metamorphosis of some coral larvae species (e.g. Nakamura et al. 2011), but not fishes. Negative impacts on early life history biology are particularly significant for the maintenance of genetic diversity and for the re-establishment of corals after disturbances such as mass bleaching events.

For other reef organisms, such as fishes, ocean acidification may compromise sensory systems, impair behaviour (dotted arrows between ocean acidification and resource availability in Fig. 1e; Munday et al. 2014; Nilsson et al. 2012) and increase energetic costs to compensate tissue acidosis (Pörtner and Farrell 2008). Results from these studies suggest that fish exposed to near-future $\mathrm{CO}_{2}$ levels exhibit impaired olfaction (e.g. distinguishing the smell of a predator; Dixson et al. 2010; Munday et al. 2009, 2014), decision-making and learning (Chivers et al. 2014; Domenici et al. 2012; Ferrari et al. 2012). Some fish even exhibit bolder behaviour and increased anxiety when exposed to elevated $\mathrm{CO}_{2}$ (Hamilton et al. 2014; Munday et al. 2013, 2014). However, the effects of near-future $\mathrm{CO}_{2}$ levels on physiological performance have been mixed. While some species appear to be negatively affected (Munday et al. 2009), other species exposed to elevated $\mathrm{CO}_{2}$ exhibit either no change (Couturier et al. 2013; Yates and Halley 2006) or even exhibit enhanced scope for aerobic performance (dotted green arrows between ocean acidification and resource availability in Fig. 1e; Couturier et al. 2013; Munday et al. 2014; Rummer et al. 2013). Furthermore, studies have found that rearing fish under near-future $\mathrm{CO}_{2}$ levels resulted in increases in reproduction and larger larvae and juveniles in comparison with control counterparts (Miller et al. 2012, 2013). Although current evidence suggests that coral reef fishes can maintain or even enhance the scope for aerobic metabolic performance under elevated $\mathrm{CO}_{2}$, there is considerable variation among species' level responses to elevated $\mathrm{CO}_{2}$ and ocean acidification, as reflected in studies on behaviour. Therefore, trade-offs likely exist among critical life history traits (e.g. behaviour and physiological performance) that are not yet 
well understood, but could result in serious implications for the replenishment of fish populations and patterns of population connectivity in coral reef ecosystems. Impact pathways through resource availability, fishery and societal well-being have not been conclusively demonstrated because ocean acidification processes will unfold over multi-decadal timescales.

\section{Caveats and future considerations}

Our attempts to highlight the multiple impact pathways through which climate change will affect coral reef socialecological systems represent an important first step in synthesizing and guiding this emerging field of research, but has some shortcomings that could potentially be addressed as new research becomes available. Most notably, our synthesis focused on the direct impacts of four key climate drivers, but synergistic impacts, feedbacks and indirect impact pathways will likely potentially play an even more important role, and our appreciation of such impacts is currently very limited. Even among the direct impacts, there are major differences in the understanding and confidence surrounding impact pathways, partly attributable to differences in the timing of impacts (e.g. there are already impacts from SST and storms, whereas sea level rise and ocean acidification impacts will take time to emerge). As such, we fully expect that new impact pathways will emerge with ongoing research in this field. Even so, it is important to document the diverse impact pathways that are already apparent or understood, in order to develop a complete understanding of the impacts of climate change, as well as developing appropriate management actions to mitigate climate change impacts in coral reef social-ecological systems.

Documenting the impacts of interacting pathways will become increasingly critical as novel, unanticipated interactions emerge. For example, ocean acidification is likely to increase susceptibility of corals to the mechanical damage caused by storms because reductions in $\mathrm{pH}$ reduce coral skeleton density and strength (Hoegh-Guldberg et al. 2007; Madin et al. 2008). Decreases in calcification rates may also be exacerbated with associated increases in ocean temperature, as has already been observed for crustose coralline algae (Anthony et al. 2008; Martin and Gattuso 2009). However, to date, observational and experimental research on how synergies between key climate drivers affect coral reef systems is very limited (Ban et al. 2014). Consequently, our synthesis focused on each individual driver, rather than potential synergies among them. As more research on synergistic impacts becomes available, this will be a crucial area of research. Similarly, feedbacks between social and ecological dynamics can exacerbate the impacts of key climate drivers (Cinner et al. 2011). However, empirical and experimental research on how key climate drivers may create feedbacks in coral reef socialecological is also limited (Nyström et al. 2012).

Some of the biggest impacts from climate change may be the indirect and unpredictable pathways on human responses, policies and changing market structures. Much of the uncertainty about the impacts of climate change on social-ecological systems arises due to the variability of human responses to change. In many instances, these linked dynamics have the potential to create both positive and negative feedbacks between social and ecological domains. For example, reduced fisheries yields associated with climate change (Cheung et al. 2009) may cause some fishers to exit the fishery (reducing fishing pressure, thus dampening environmental impacts), while other fishers may increase effort to supplement losses (potentially amplifying environmental impacts) (Cinner et al. 2011). Already in Mozambique, small-scale fishers have begun to fish into the open ocean in response to declining inshore catches resulting from overfishing; their un-motorized vessels are ill-equipped to cope with increasingly severe tropical storms leading, in the worst cases, to loss of lives (Blythe et al. 2013). At a larger scale, policy responses, motivated by a range of agendas from personal to political, will feedback into reef systems with differential impacts on individuals, groups and societies. In the Maldives, for example, climate change adaptation discourses are being used to legitimize unfavourable government resettlement programs, despite resistance from local people (Kothari 2014). Changing market structures, political unrest and demographic trends in coral reef-dependent societies will likely interact with key climate drivers to produce profound changes in the social-ecological system. Yet, to date, research on these types of impacts is extremely limited (Daw et al. 2009). Considerable research is required into the range of motivation and impacts of people's responses to climate change (Barnett and O'Neill 2010; Marino and Ribot 2012), and also how climate change will differentially impact cultures, geographies and segments of societies.

\section{Conclusion}

This study highlights a diversity of pathways in which sustained and ongoing climate change will impact coral reef ecosystems and reef-dependent societies. The relative importance of different linkages and major impact pathways varies according to the specific climate drivers being considered. For example, sea level rise is likely to only have strong direct impacts on societal well-being, but limited direct impacts on reef ecosystems. In contrast, 
ocean warming will have direct impacts to multiple components of coral reef ecosystems, with flow-on effects to societal well-being. Despite these important differences, existing research into impacts of climate change on coral reefs is highly biased towards one or two key pathways, which almost invariably ascribe major impacts on human societies to declines in overall fisheries yields (e.g. Cinner et al. 2012), largely ignoring broader understandings of climate impacts on societal well-being that are becoming established in other social-ecological systems (e.g. Adger et al. 2005) and the potential for bi-directionality. An important corollary of this is that that established links are as much a reflection of inherent bias in prior research, as they are indicative of major links and impact pathways.

By explicitly highlighting the specific pathways through which climate drivers can directly or indirectly influence ecosystems and societies, we hope to stimulate research into previously overlooked (or poorly understood), but potentially important pathways, to expedite a more comprehensive understanding of climate impacts on socialecological systems associated with coral reefs. Most notably, there needs to be increased attention given to nonfisheries linkages between reef environments and reef-dependent societies. Notwithstanding emergence of even more diverse impact pathways, this will provide a more thorough and comprehensive understanding of the impacts of climate change, illustrating how impacts on coral reef environments can and will affect reef-dependent societies, and that societal responses may in turn impact on natural resources and the environment. This is fundamental in developing appropriate management actions to mitigate climate change impacts in coral reef social-ecological systems.

Acknowledgments This work was funded by the ARC Centre of Excellence for Coral Reef Studies, as part of an early career researcher development workshop.

\section{References}

Adger WN, Hughes TP, Folke C, Carpenter SR, Röckstrom J (2005) Social-ecological resilience to coastal disasters. Science 309:1036-1039. doi:10.1126/science.1112122

Albright R, Langdon C, Anthony KRN (2013) Dynamics of seawater carbonate chemistry, production, and calcification of a coral reef flat, central Great Barrier Reef. Biogeosciences 10:6747-6758. doi:10.5194/bg-10-6747-2013

Allison EH, Perry AL, Badjeck M-C, Adger WN, Brown K, Conway D, Halls AS, Pilling GM, Reynolds JD, Andrew NL, Dulvy NK (2009) Vulnerability of national economies to the impacts of climate change on fisheries. Fish Fish 10:173-196. doi:10.1111/ j.1467-2979.2008.00310.x

Anthony KRN, Kline DI, Diaz-Pulido G, Dove S, Hoegh-Guldberg O (2008) Ocean acidification causes bleaching and productivity loss in coral reef builders. Proc Natl Acad Sci USA 105:17442-17446. doi:10.1073/pnas.0804478105
Badjeck MC, Allison EH, Halls AS, Dulvy NK (2010) Impacts of climate variability and change on fishery-based livelihoods. Mar Policy 34:375-383. doi:10.1016/j.marpol.2009.08.007

Baird AH, Campbell SJ, Anggoro AW, Ardiwijaya RL, Fadli N, Herdiana Y, Kartawijaya T, Mahyiddin D, Mukminin A, Pardede ST, Pratchett MS, Rudi E, Siregar AM (2005) Acehnese reefs in the wake of the Asian tsunami. Curr Biol 15:1926-1930. doi:10. 1016/j.cub.2005.09.036

Ban SS, Graham NAJ, Connolly SR (2014) Evidence for multiple stressor interactions and effects on coral reefs. Global Change Biol 20:681-697

Barange M, Merino G, Blanchard JL, Scholtens J, Harle J, Allison EH, Allen JI, Holt J, Jennings S (2014) Impacts of climate change on marine ecosystem production in societies dependent on fisheries. Nat Clim Change 4:211-216. doi:10.1038/ Nclimate2119

Barnett J, O'Neill S (2010) Maladaptation. Global Environ Chang 20:211-213. doi:10.1016/j.gloenvcha.2009.11.004

Baschieri A, Kovats S (2010) Climate and child health in rural areas of low and middle income countries: a review of the epidemiological evidence. Int Public Health J 2:431-445

Bell JD, Ganachaud A, Gehrke PC, Griffiths SP, Hobday AJ, HoeghGuldberg O, Johnson JE, Le Borgne R, Lehodey P, Lough JM, Matear RJ, Pickering TD, Pratchett MS, Gupta AS, Senina I, Waycott M (2013) Mixed responses of tropical Pacific fisheries and aquaculture to climate change. Nat Clim Change 3:591-599. doi:10.1038/Nclimate 1838

Béné C, Wood RG, Newsham A, Davies M (2012) Resilience: new utopia or new tyranny? Reflection about the potentials and limits of the concept of resilience in relation to vulnerability reduction programmes. IDS Working Papers 2012, pp 1-61. doi:10.1111/j. 2040-0209.2012.00405.x

Black R, Bennett SRG, Thomas SM, Beddington JR (2011) Migration as adaptation. Nature 478:447-449

Blanchon P, Eisenhauer A, Fietzke J, Liebetrau V (2009) Rapid sealevel rise and reef back-stepping at the close of the last interglacial highstand. Nature 458:881-884

Blythe JL, Murray G, Flaherty MS (2013) Historical perspectives and recent trends in the coastal Mozambican fishery. Ecol Soc 18:65. doi:10.5751/Es-05759-180465

Bridges KW, McClatchey WC (2009) Living on the margin: Ethnoecological insights from Marshall Islanders at Rongelap atoll. Global Environ Change 19:140-146. doi:10.1016/j.gloenv cha.2009.01.009

Burge CA, Friedman CS, Froelich B, Hershberger PK, Hofmann EE, Petes LE, Prager KC, Weil E, Willis BL, Ford SE, Harvell CD (2014) Climate change influences on marine infectious diseases: implications for management and society. Annu Rev Mar Sci 6:249-277. doi:10.1146/annurev-marine-010213-135029

Burke L, Reytar K, Spalding M, Perry A (2011) Reefs at risk revisited. World Resources Institute, Washington DC

Burrows MT, Schoeman DS, Richardson AJ, Molinos JG, Hoffmann A, Buckley LB, Moore PJ, Brown CJ, Bruno JF, Duarte CM, Halpern BS, Hoegh-Guldberg O, Kappel CV, Kiessling W, O’Connor MI, Pandolfi JM, Parmesan C, Sydeman WJ, Ferrier S, Williams KJ, Poloczanska ES (2014) Geographical limits to species-range shifts are suggested by climate velocity. Nature 507:492-495. doi:10.1038/Nature12976

Butler CD, Oluoch-Kosura W (2006) Linking future ecosystem services and future human well-being. Ecol Soc 11:30

Caldeira K, Wickett ME (2003) Anthropogenic carbon and ocean pH. Nature 425:365. doi:10.1038/425365a

Callaghan J, Power SB (2011) Variability and decline in the number of severe tropical cyclones making land-fall over eastern Australia since the late nineteenth century. Clim Dynam 37:647-662. doi:10.1007/s00382-010-0883-2 
Carpenter SR, Mooney HA, Agard J, Capistrano D, DeFries RS, Díaz S, Dietz T, Duraiappah AK, Oteng-Yeboah A, Pereira HM, Perrings C, Reid WV, Sarukhan J, Scholes RJ, Whyte A (2009) Science for managing ecosystem services: beyond the Millennium Ecosystem Assessment. $P$ Natl Acad Sci USA 106:1305-1312. doi:10.1073/pnas.0808772106

Ceccarelli D, Colwell RR (2014) Vibrio ecology, pathogenesis, and evolution. Front Microbiol 5:256

Chateau-Degat ML, Chinain M, Cerf N, Gingras S, Hubert B, Dewailly E (2005) Seawater temperature, Gambierdiscus spp. variability and incidence of ciguatera poisoning in French Polynesia. Harmful Algae 4:1053-1062. doi:10.1016/j.hal.2005. 03.003

Cheal AJ, Emslie M, MacNeil MA, Miller I, Sweatman H (2013) Spatial variation in the functional characteristics of herbivorous fish communities and the resilience of coral reefs. Ecol Appl 23:174-188

Cheung WWL, Lam VWY, Sarmiento JL, Kearney K, Watson R, Pauly D (2009) Projecting global marine biodiversity impacts under climate change scenarios. Fish Fish 10:235-251. doi:10. 1111/j.1467-2979.2008.00315.x

Cheung WWL, Lam VWY, Sarmiento JL, Kearney K, Watson REG, Zeller D, Pauly D (2010) Large-scale redistribution of maximum fisheries catch potential in the global ocean under climate change. Global Change Biol 16:24-35. doi:10.1111/j.1365-2486. 2009.01995.x

Chivers DP, McCormick MI, Nilsson GE, Munday PL, Watson SA, Meekan MG, Mitchell MD, Corkill KC, Ferrari MC (2014) Impaired learning of predators and lower prey survival under elevated $\mathrm{CO}_{2}$ : a consequence of neurotransmitter interference. Global Change Biol 20:515-522. doi:10.1111/Gcb.12291

Cinner JE, Folke C, Daw T, Hicks CC (2011) Responding to change: Using scenarios to understand how socioeconomic factors may influence amplifying or dampening exploitation feedbacks among Tanzanian fishers. Global Environ Change 21:7-12. doi:10.1016/j.gloenvcha.2010.09.001

Cinner JE, McClanahan TR, Graham NAJ, Daw TM, Maina J, Stead SM, Wamukota A, Brown K, Bodin Ö (2012) Vulnerability of coastal communities to key impacts of climate change on coral reef fisheries. Global Environ Change 22:12-20. doi:10.1016/j. gloenvcha.2011.09.018

Cinner JE, Huchery C, Darling ES, Humphries AT, Graham NA, Hicks CC, Marshall N, McClanahan TR (2013) Evaluating social and ecological vulnerability of coral reef fisheries to climate change. PLoS One 8:e74321. doi:10.1371/journal.pone.0074321

Collins M, Knutti R, Arblaster J, Dufresne JL, Fichefet T, Friedlingstein P, Gao X, Gutowski WJ, Johns T, Krinner G, Shongwe M, Tebaldi C, Weaver AJ, Wehner M (2013) Long-term climate change: projections, commitments and irreversibility. In: Stocker TF, Qin D, Plattner GK, Tignor M, Allen SK, Boschung AJ, Nauels A, Xia Y, Bex V, Midgley PM (eds) Climate Change 2013: The Physical Science Basis. Contribution of Working Group I to the Fifth Assessment Report of the Intergovernmental Panel on Climate Change. Cambridge University Press, Cambridge. doi:10.1017/CB09781107415324.024

Couturier CS, Stecyk JAW, Rummer JL, Munday PL, Nilsson GE (2013) Species-specific effects of near-future $\mathrm{CO}_{2}$ on the respiratory performance of two tropical prey fish and their predator. Comp Biochem Physiol A 166:482-489. doi:10.1016/j. cbpa.2013.07.025

Daufresne M, Lengfellner K, Sommer U (2009) Global warming benefits the small in aquatic ecosystems. Proc Natl Acad Sci USA 106:12788-12793. doi:10.1073/pnas.0902080106

Daw T, Adger WN, Brown K, Badjeck M-C (2009) Climate change and capture fisheries: potential impacts, adaptation and mitigation. In: Cochrane K, De Young C, Soto D, Bahri T (eds)
Climate change implications for fisheries and aquaculture: overview of current scientific knowledge, vol FAO Fisheries and Aquaculture Technical Paper. No. 530. FAO, Rome

De'ath G, Lough JM, Fabricius KE (2009) Declining coral calcification on the Great Barrier Reef. Science 323:116-119. doi:10. 1126/science. 1165283

De'ath G, Fabricius KE, Sweatman H, Puotinen M (2012) The 27-year decline of coral cover on the Great Barrier Reef and its causes. Proc Natl Acad Sci USA 109:17995-17999. doi:10.1073/ pnas. 1208909109

Dillon ME, Wang G, Huey RB (2010) Global metabolic impacts of recent climate warming. Nature 467:U704-U788. doi:10.1038/ Nature09407

Dissard D, Douville E, Reynaud S, Juillet-Leclerc A, Montagna P, Louvat P, McCulloch M (2012) Light and temperature effects on $11 \mathrm{~B}$ and $\mathrm{B} / \mathrm{Ca}$ ratios of the zooxanthellate coral Acropora sp.: results from culturing experiments. Biogeosciences 9:4589-4605. doi:10.5194/bg-9-4589-2012

Dixson DL, Munday PL, Jones GP (2010) Ocean acidification disrupts the innate ability of fish to detect predator olfactory cues. Ecol Lett 13:68-75. doi:10.1111/j.1461-0248.2009.01400.x

Domenici P, Allan B, McCormick MI, Munday PL (2012) Elevated carbon dioxide affects behavioural lateralization in a coral reef fish. Biol Lett 8:78-81. doi:10.1098/rsbl.2011.0591

Donelson JM, Munday PL, McCormick MI, Pankhurst NW, Pankhurst PM (2010) Effects of elevated water temperature and food availability on the reproductive performance of a coral reef fish. Mar Ecol Prog Ser 401:233-243. doi:10.3354/Meps08366

Doney SC, Fabry VJ, Feely RA, Kleypas JA (2009) Ocean acidification: The other $\mathrm{CO}_{2}$ problem. Annu Rev Mar Sci 1:169-192. doi:10.1146/annurev.marine.010908.163834

Donner SD (2009) Coping with commitment: projected thermal stress on coral reefs under different future scenarios. PLoS One 4:e5712. doi:10.1371/journal.pone.0005712

Donner SD, Skirving WJ, Little CM, Oppenheimer M, HoeghGuldberg O (2005) Global assessment of coral bleaching and required rates of adaptation under climate change. Global Change Biol 11:2251-2265. doi:10.1111/j.1365-2486.2005.01073.x

Eakin CM, Morgan JA, Heron SF, Smith TB, Liu G, Alvarez-Filip L, Baca B, Bartels E, Bastidas C, Bouchon C, Brandt M, Bruckner AW, Bunkley-Williams L, Cameron A, Causey BD, Chiappone M, Christensen TR, Crabbe MJ, Day O, de la Guardia E, DíazPulido G, DiResta D, Gil-Agudelo DL, Gilliam DS, Ginsburg RN, Gore S, Guzmán HM, Hendee JC, Hernández-Delgado EA, Husain E, Jeffrey CF, Jones RJ, Jordán-Dahlgren E, Kaufman LS, Kline DI, Kramer PA, Lang JC, Lirman D, Mallela J, Manfrino C, Maréchal JP, Marks K, Mihaly J, Miller WJ, Mueller EM, Muller EM, Orozco Toro CA, Oxenford HA, Ponce-Taylor D, Quinn N, Ritchie KB, Rodríguez S, Ramírez AR, Romano S, Samhouri JF, Sánchez JA, Schmahl GP, Shank BV, Skirving WJ, Steiner SC, Villamizar E, Walsh SM, Walter C, Weil E, Williams EH, Roberson KW, Yusuf Y (2010) Caribbean corals in crisis: Record thermal stress, bleaching, and mortality in 2005. PLoS One 5:e13969. doi:10.1371/journal. pone.0013969

Elsner JB, Kossin JP, Jagger TH (2008) The increasing intensity of the strongest tropical cyclones. Nature 455:92-95. doi:10.1038/ Nature07234

Fabricius KE, Wolanski E (2000) Rapid smothering of coral reef organisms by muddy marine snow. Estuar Coast Shelf Sci 50:115-120. doi:10.1006/ecss.1999.0538

Fabricius KE, Langdon C, Uthicke S, Humphrey C, Noonan S, Death G, Okazaki R, Muehllehner N, Glas MS, Lough JM (2011) Losers and winners in coral reefs acclimatized to elevated carbon dioxide concentrations. Nat Clim Change 1:165-169. doi:10. 1038/nclimate 1122 
Farbotko C, Lazrus H (2012) The first climate refugees? Contesting global narratives of climate change in Tuvalu. Global Environ Change 22:382-390. doi:10.1016/j.gloenvcha.2011.11.01

Fenner DP (1991) Effects of hurricane Gilbert on coral reefs, fishes and sponges at Cozumel, Mexico. Bull Mar Sci 48:719-730

Ferrari MCO, McCormick MI, Munday PL, Meekan MG, Dixson DL, Lonnstedt O, Chivers DP (2012) Effects of ocean acidification on visual risk assessment in coral reef fishes. Funct Ecol 26:553-558. doi:10.1111/j.1365-2435.2011.01951.x

Figueiredo J, Baird AH, Harii S, Connolly SR (2014) Increased local retention of reef coral larvae as a result of ocean warming. Nat Clim Change 4:498-502. doi:10.1038/nclimate2210

Fulton CJ, Depczynski M, Holmes TH, Noble MM, Radford B, Wernberg T, Wilson SK (2014) Sea temperature shapes seasonal fluctuations in seaweed biomass within the Ningaloo coral reef ecosystem. Limnol Oceanogr 59:156-166. doi:10.4319/lo.2014. 59.01 .0156

Goatley CHR, Bellwood DR (2012) Sediment suppresses herbivory across a coral reef depth gradient. Biol Lett 8:1016-1018. doi:10. 1098/rsbl.2012.0770

Goto K, Miyagi K, Kawana T, Takahashi J, Imamura F (2011) Emplacement and movement of boulders by known storm waves-field evidence from the Okinawa Islands, Japan. Mar Geol 283:66-78. doi:10.1016/j.margeo.2010.09.007

Graham NAJ, Nash KL (2013) The importance of structural complexity in coral reef ecosystems. Coral Reefs 32:315-326. doi:10.1007/s00338-012-0984-y

Graham NAJ, Wilson SK, Jennings S, Polunin NVC, Bijoux JP, Robinson J (2006) Dynamic fragility of oceanic coral reef ecosystems. Proc Natl Acad Sci USA 103:8425-8429. doi:10. 1073/pnas.0600693103

Graham NAJ, Wilson SK, Jennings S, Polunin NVC, Robinson JAN, Bijoux JP, Daw TM (2007) Lag effects in the impacts of mass coral bleaching on coral reef fish, fisheries, and ecosystems. Conserv Biol 21:1291-1300. doi:10.1111/j.1523-1739.2007. 00754.X

Graham NAJ, Cinner JE, Norström AV, Nyström M (2014) Coral reefs as novel ecosystems: embracing new futures. Curr Opin Environ Sustain 7:9-14. doi:10.1016/j.cosust.2013.11.023

Guadayol O, Silbiger NJ, Donahue MJ, Thomas FIM (2014) Patterns in temporal variability of temperature, oxygen and $\mathrm{pH}$ along an environmental gradient in a coral reef. PLoS One 9:e85213. doi:10.1371/journal.pone.0085213

Haig J, Nott J, Reichart GJ (2014) Australian tropical cyclone activity lower than at any time over the past 550-1,500 years. Nature 505:667-671. doi:10.1038/Nature12882

Halford A, Cheal AJ, Ryan D, Williams DM (2004) Resilience to large-scale disturbance in coral and fish assemblages on the Great Barrier Reef. Ecology 85:1892-1905. doi:10.1890/034017

Hallegraeff GM (2010) Ocean climate change, phytoplankton community responses, and harmful algal blooms: a formidable predictive challenge. J Phycol 46:220-235. doi:10.1111/j.15298817.2010.00815.x

Hamilton TJ, Holcombe A, Tresguerres M (2014) $\mathrm{CO}_{2}$-induced ocean acidification increases anxiety in Rockfish via alteration of GABA(A) receptor functioning. Proc $\mathrm{R}$ Soc $\mathrm{B}$ Biol Sci 281:20132509. doi:10.1098/Rspb.2013.2509

Harmelin-Vivien ML (1994) The effects of storms and cyclones on coral reefs: a review. J Coast Res 12:211-231

Hartmann DL, Klein Tank AMG, Rusticucci M, Alexander LV, Brönnimann S, Charabi Y, Dentener FJ, Dlugokencky EJ, Easterling DR, Kaplan A, Soden BJ, Thorne PW, Wild M, Zhai PM (2013) Observations: atmosphere and surface. In: Stocker TF, Qin D, Plattner GK, Tignor M, Allen SK, Boschung AJ, Nauels A, Xia Y, Bex V, Midgley PM (eds) Climate change
2013: the physical science basis. Contribution of Working Group I to the Fifth Assessment Report of the Intergovernmental Panel on Climate Change. Cambridge University Press, Cambridge. doi: $10.1017 / \mathrm{CB} 09781107415324.008$

Heupel MR, Simpfendorfer CA, Hueter RE (2003) Running before the storm: blacktip sharks respond to falling barometric pressure associated with Tropical Storm Gabrielle. J Fish Biol 63:1357-1363. doi:10.1046/j.1095-8649.2003.00250.x

Heyward AJ, Negri AP (2010) Plasticity of larval pre-competency in response to temperature: observations on multiple broadcast spawning coral species. Coral Reefs 29:631-636. doi:10.1007/ s00338-009-0578-5

Hicks CC (2011) How do we value our reefs? Risks and tradeoffs across scales in "biomass-based" economies. Coast Managt 39:358-376. doi:10.1080/08920753.2011.589219

Hoegh-Guldberg O, Mumby PJ, Hooten AJ, Steneck RS, Greenfield P, Gomez E, Harvell CD, Sale PF, Edwards AJ, Caldeira K, Knowlton N, Eakin CM, Iglesias-Prieto R, Muthiga N, Bradbury RH, Dubi A, Hatziolos ME (2007) Coral reefs under rapid climate change and ocean acidification. Science 318:1737-1742. doi:10.1126/science.1152509

Hofmann GE, Smith JE, Johnson KS, Send U, Levin LA, Micheli F, Paytan A, Price NN, Peterson B, Takeshita Y, Matson PG, Crook ED, Kroeker KJ, Gambi MC, Rivest EB, Frieder CA, Yu PC, Martz TR (2011) High-frequency dynamics of ocean pH: a multi-ecosystem comparison. PLoS One 6:e28983. doi:10.1371/ journal.pone.0028983

Howells EJ, Berkelmans R, van Oppen MJH, Willis BL, Bay LK (2013) Historical thermal regimes define limits to coral acclimatization. Ecology 94:1078-1088. doi:10.1890/12-1257.1

Hoyos CD, Agudelo PA, Webster PJ, Curry JA (2006) Deconvolution of the factors contributing to the increase in global hurricane intensity. Science 312:94-97. doi:10.1126/science. 1123560

Hughes L (2000) Biological consequences of global warming: is the signal already apparent? Trends Ecol Evol 15:56-61. doi:10. 1016/S0169-5347(99)01764-4

Hughes TP, Baird AH, Bellwood DR, Card M, Connolly SR, Folke C, Grosberg R, Hoegh-Guldberg O, Jackson JB, Kleypas J, Lough JM, Marshall P, Nyström M, Palumbi SR, Pandolfi JM, Rosen B, Roughgarden J (2003) Climate change, human impacts, and the resilience of coral reefs. Science 301:929-933. doi:10.1126/ science. 1085046

Hughes TP, Graham NAJ, Jackson JBC, Mumby PJ, Steneck RS (2010) Rising to the challenge of sustaining coral reef resilience. Trends Ecol Evol 25:633-642. doi:10.1016/j.tree.2010.07.011

Kawabata Y, Okuyama J, Asami K, Okuzawa K, Yoseda K, Arai N (2010) Effects of a tropical cyclone on the distribution of hatchery-reared black-spot tuskfish Choerodon schoenleinii determined by acoustic telemetry. J Fish Biol 77:627-642. doi:10.1111/j.1095-8649.2010.02702.x

Kirtman B, Power SB, Adedoyin JA, Boer GJ, Bojariu R, Camilloni I, Doblas-Reyes FJ, Fiore AM, Kimoto M, Meehl GA, Prather M, Sarr A, Schär C, Sutton R, van Oldenborgh GJ, Vecchi G, Wang HJ (2013) Near-term climate change: projections and predictability. In: Stocker TF, Qin D, Plattner GK, Tignor M, Allen SK, Boschung AJ, Nauels A, Xia Y, Bex V, Midgley PM (eds) Climate Change 2013: the physical science basis. Contribution of Working Group I to the Fifth Assessment Report of the Intergovernmental Panel on Climate Change. Cambridge University Press, Cambridge. doi:10.1017/CB09781107415324. 023

Kittinger JN, Finkbeiner EM, Glazier EW, Crowder LB (2012) Human dimensions of coral reef social-ecological systems. Ecol Soc 17:17. doi:10.5751/ES-05115-170417

Kleypas JA, Langdon C (2006) Coral reefs and changing seawater chemistry. Chapter 5. In: Phinney JT, Hoegh-Guldberg O, 
Kleypas J, Skirving W, Strong A (eds) Coral Reefs and Climate Change: Science and Management, vol 61. AGU Monograph Series. Coastal and Estuarine Studies, American Geophysical Union, Washington DC

Kleypas JA, Yates KK (2009) Coral reefs and ocean acidification. Oceanography 22:108-117

Klotzbach PJ (2006) Trends in global tropical cyclone activity over the past twenty years (1986-2005). Geophys Res Lett 33:L10805. doi:10.1029/2006g1025881

Knutson TR, McBride JL, Chan J, Emanuel K, Holland G, Landsea C, Held I, Kossin JP, Srivastava AK, Sugi M (2010) Tropical cyclones and climate change. Nat Geosci 3:157-163. doi:10. 1038/Ngeo779

Kothari U (2014) Political discourses of climate change and migration: resettlement policies in the Maldives. Geogr $\mathrm{J}$ 180:130-140. doi:10.1111/Geoj.12032

Kronen M, Vunisea A (2009) Fishing impact and food security—gender differences in finfisheries across Pacific Island countries and cultural groups. Secretariat of the Pacific Community Women in Fisheries Information Bulletin 19. http://www.spc.int/coastfish/en/publica tions/bulletins/women-in-fisheries/115-women-in-fisheries-informa tion-bulletin-19.html

Landsea CW, Harper BA, Hoarau K, Knaff JA (2006) Can we detect trends in extreme tropical cyclones? Science 313:452-454. doi:10.1126/science. 1128448

Langdon C, Atkinson MJ (2005) Effect of elevated pCO(2) on photosynthesis and calcification of corals and interactions with seasonal change in temperature/irradiance and nutrient enrichment. J Geophys Res Oceans 110:s07. doi:10.1029/2004jc002576

Lassig BR (1983) The effects of a cyclonic storm on coral reef assemblages. Environ Biol Fish 9:55-63

Lipp EK, Huq A, Colwell RR (2002) Effects of global climate on infectious disease: the cholera model. Clin Microbiol Rev 15:757-770. doi:10.1128/cmr.15.4.757-770.2002

Locascio JV, Mann DA (2005) Effects of hurricane Charley on fish chorusing. Biol Lett 1:362-365. doi:10.1098/rsbl.2005.0309

Lough JM (2012) Small change, big difference: sea surface temperature distributions for tropical coral reef ecosystems, 1950-2011. J Geophys Res Oceans 117:C09018. doi:10.1029/2012jc008199

MacNeil MA, Graham NA, Cinner JE, Dulvy NK, Loring PA, Jennings S, Polunin NV, Fisk AT, McClanahan TR (2010) Transitional states in marine fisheries: adapting to predicted global change. Philos Trans R Soc B 365:3753-3763. doi:10. 1098/rstb.2010.0289

Madin JS, O’Donnell MJ, Connolly SR (2008) Climate-mediated mechanical changes to post-disturbance coral assemblages. Biol Lett 4:490-493. doi:10.1098/rsbl.2008.0249

Mahon R (2002) Adaptation of fisheries and fishing communities to the impacts of climate change in the CARICOM region: issue paper-draft. Mainstreaming adaptation to climate change (MACC) of the Caribbean Center for Climate Change (CCCC), Washington, DC

Mallela J, Roberts C, Harrod C, Goldspink CR (2007) Distributional patterns and community structure of Caribbean coral reef fishes within a river-impacted bay. J Fish Biol 70:523-537. doi:10. 1111/j.1095-8649.2007.01323.x

Marino E (2012) The long history of environmental migration: assessing vulnerability construction and obstacles to successful relocation in Shishmaref, Alaska. Global Environ Change 22:374-381. doi:10.1016/j.gloenvcha.2011.09.016

Marino E, Ribot J (2012) Special issue introduction: adding insult to injury: climate change and the inequities of climate intervention. Global Environ Change 22:323-328. doi:10.1016/j.gloenvcha. 2012.03.001

Marshall P, Marshall N (2012) Extreme weather: adaptation insights from the Great Barrier Reef. Marine Adaptation Bulletin (MAB), vol 3, Issue 4, Summer 2011-2012. http://arnmbr.org/content/ index.php/site/resources_extended/mab_v3_i4_marshall

Martin S, Gattuso JP (2009) Response of Mediterranean coralline algae to ocean acidification and elevated temperature. Global Change Biol 15:2089-2100. doi:10.1111/j.1365-2486.2009. 01874.x

McAdoo BG, Ah-Leong JS, Bell L, Ifopo P, Ward J, Lovell E, Skelton P (2011) Coral reefs as buffers during the 2009 South Pacific tsunami, Upolu Island, Samoa. Earth-Sci Rev 107:147-155. doi:10.1016/j.earscirev.2010.11.005

McCarthy J, Canziani O, Leary N, Dokken D, White K (eds) (2001) Climate change 2001: impacts, adaptation \& vulnerability. Cambridge University Press, Cambridge

McClanahan TR (2004) The relationship between bleaching and mortality of common corals. Mar Biol 144:1239-1245. doi:10. 1007/s00227-003-1271-9

McClanahan TR, Cinner J (2012) Adapting to a changing environment: confronting the consequences of climate change. Oxford University Press, New York

McClanahan TR, Hicks CC, Darling ES (2008) Malthusian overfishing and efforts to overcome it on Kenyan coral reefs. Ecol Appl 18:1516-1529. doi:10.1890/07-0876.1

McClanahan TR, Weil E, Cortés J, Baird AH, Ateweberhan M (2009) Consequences of coral bleaching for sessile reef organisms. In: van Oppen MJHLJ (ed) Coral bleaching. Springer-Verlag, Berlin

McCulloch M, Falter J, Trotter J, Montagna P (2012) Coral resilience to ocean acidification and global warming through $\mathrm{pH}$ upregulation. Nat Clim Change 2:623-633. doi:10.1038/ Nclimate 1473

McLeod IM, Rummer JL, Clark TD, Jones GP, McCormick MI, Wenger AS, Munday PL (2013) Climate change and the performance of larval coral reef fishes: the interaction between temperature and food availability. Conserv Physiol 1:cot024. doi:10.1093/conphys/cot024

Messmer V, Jones GP, Munday PL, Holbrook SJ, Schmitt RJ, Brooks AJ (2011) Habitat biodiversity as a determinant of fish community structure on coral reefs. Ecology 92:2285-2298

Miller GM, Watson SA, Donelson JM, McCormick MI, Munday PL (2012) Parental environment mediates impacts of increased carbon dioxide on a coral reef fish. Nat Clim Change 2:858-861. doi:10.1038/Nclimate1599

Miller GM, Watson SA, McCormick MI, Munday PL (2013) Increased $\mathrm{CO}_{2}$ stimulates reproduction in a coral reef fish. Global Change Biol 19:3037-3045. doi:10.1111/Gcb.12259

Munday PL, Jones GP, Pratchett MS, Williams AJ (2008) Climate change and the future for coral reef fishes. Fish Fish 9:261-285. doi:10.1111/j.1467-2979.2008.00281.x

Munday PL, Dixson DL, Donelson JM, Jones GP, Pratchett MS, Devitsina GV, Doving KB (2009) Ocean acidification impairs olfactory discrimination and homing ability of a marine fish. Proc Natl Acad Sci USA 106:1848-1852. doi:10.1073/pnas. 0809996106

Munday PL, McCormick MI, Nilsson GE (2012) Impact of global warming and rising $\mathrm{CO}_{2}$ levels on coral reef fishes: what hope for the future? J Exp Biol 215:3865-3873. doi:10.1242/Jeb.074765

Munday P, Pratchett M, Dixson D, Donelson J, Endo GK, Reynolds A, Knuckey R (2013) Elevated $\mathrm{CO}_{2}$ affects the behavior of an ecologically and economically important coral reef fish. Mar Biol 160:2137-2144. doi:10.1007/s00227-012-2111-6

Munday PL, Cheal AJ, Dixson DL, Rummer JL, Fabricius KE (2014) Behavioural impairment in reef fishes caused by ocean acidification at $\mathrm{CO}_{2}$ seeps. Nat Clim Change 4:487-492. doi:10.1038/ nclimate 2195

Nakamura M, Ohki S, Suzuki A, Sakai K (2011) Coral larvae under ocean acidification: survival, metabolism, and metamorphosis. PLoS One 6:e14521. doi:10.1371/journal.pone.0014521 
Nilsson GE, Dixson DL, Domenici P, McCormick MI, Sorensen C, Watson SA, Munday PL (2012) Near-future carbon dioxide levels alter fish behaviour by interfering with neurotransmitter function. Nat Clim Change 2:201-204. doi:10.1038/ Nclimate 1352

Nott J, Hayne M (2001) High frequency of 'super-cyclones' along the Great Barrier Reef over the past 5,000 years. Nature 413:508-512. doi:10.1038/35097055

Nyström M, Norström A, Blenckner T, de la Torre-Castro M, Eklöf JS, Folke C, Österblom H, Steneck RS, Thyresson M, Troell M (2012) Confronting feedbacks of degraded marine ecosystems. Ecosystems 15:695-710. doi:10.1007/s10021-012-9530-6

O'Connor MI, Bruno JF, Gaines SD, Halpern BS, Lester SE, Kinlan BP, Weiss JM (2007) Temperature control of larval dispersal and the implications for marine ecology, evolution, and conservation. Proc Natl Acad Sci USA 104:1266-1271. doi:10.1073/pnas. 0603422104

Orr JC, Fabry VJ, Aumont O, Bopp L, Doney SC, Feely RA, Gnanadesikan A, Gruber N, Ishida A, Joos F, Key RM, Lindsay K, Maier-Reimer E, Matear R, Monfray P, Mouchet A, Najjar RG, Plattner GK, Rodgers KB, Sabine CL, Sarmiento JL, Schlitzer R, Slater RD, Totterdell IJ, Weirig MF, Yamanaka Y, Yool A (2005) Anthropogenic ocean acidification over the twenty-first century and its impact on calcifying organisms. Nature 437:681-686. doi:10.1038/Nature04095

Overpeck JT, Otto-Bliesner BL, Miller GH, Muhs DR, Alley RB, Kiehl JT (2006) Paleoclimatic evidence for future ice-sheet instability and rapid sea-level rise. Science 311:1747-1750. doi:10.1126/science. 1115159

Pandolfi JM, Connolly SR, Marshall DJ, Cohen AL (2011) Projecting coral reef futures under global warming and ocean acidification. Science 333:418-422. doi:10.1126/science.1204794

Pörtner HO, Farrell AP (2008) Ecology physiology and climate change. Science 322:690-692. doi:10.1126/science.1163156

Pörtner HO, Karl DM, Boyd PW, Cheung WWL, Lluch-Cota SE, Nojiri Y, Schmidt DN, Zavialov PO (2014) Ocean systems. In: Field CB, Barros VR, Dokken DJ, Mach KJ, Mastrandrea MD, Bilir TE, Chatterjee M, Ebi KL, Estrada YO, Genova RC, Girma B, Kissel ES, Levy AN, MacCracken S, Mastrandrea PR, White LL (eds) Climate Change 2014: Impacts, Adaptation, and Vulnerability. Part A: Global and Sectoral Aspects. Contribution of Working Group II to the Fifth Assessment Report of the Intergovernmental Panel on Climate Change, Cambridge University Press, Cambridge

Pratchett MS, Munday PL, Wilson SK, Graham NAJ, Cinner JE, Bellwood DR, Jones GP, Polunin NVC, Mcclanahan TR (2008) Effects of climate-induced coral bleaching on coral-reef fishesecological and economic consequences. Oceanogr Mar Biol 49:251-296

Pratchett MS, Hoey AS, Wilson SK, Messmer V, Graham NAJ (2011) Changes in biodiversity and functioning of reef fish assemblages following coral bleaching and coral loss. Diversity 3:424-452

Reuveny R (2007) Climate change-induced migration and violent conflict. Polit Geogr 26:656-673. doi:10.1016/j.polgeo.2007.05. 001

Rhein M, Rintoul SR, Aoki S, Campos E, Chambers D, Feely RA, Gulev S, Johnson GC, Josey SA, Kostianoy A, Mauritzen C, Roemmich D, Talley LD, Wang F (2013) Observations: Ocean. In: Stocker TF, Qin D, Plattner GK, Tignor M, Allen SK, Boschung AJ, Nauels A, Xia Y, Bex V, Midgley PM (eds) Climate Change 2013: The Physical Science Basis. Contribution of Working Group I to the Fifth Assessment Report of the Intergovernmental Panel on Climate Change. Cambridge University Press, Cambridge. doi:10.1017/CB09781107415324. 010
Rongo T, van Woesik R (2012) Socioeconomic consequences of ciguatera poisoning in Rarotonga, southern Cook Islands. Harmful Algae 20:92-100. doi:10.1016/j.hal.2012.08.003

Rummer JL, Stecyk JAW, Couturier CS, Watson S-A, Nilsson GE, Munday PL (2013) Elevated $\mathrm{CO}_{2}$ enhances aerobic scope of a coral reef fish. Conserv Physiol 1:cot023. doi:10.1093/conphys/ $\cot 023$

Rummer JL, Couturier CS, Stecyk JAW, Gardiner NM, Kinch JP, Nilsson GE, Munday PL (2014) Life on the edge: thermal optima for aerobic scope of equatorial reef fishes are close to current day temperatures. Global Change Biol 20:1055-1066. doi:10.1111/ Gcb. 12455

Sandin L (2009) The relationship between land-use, hydromorphology and river biota at different spatial and temporal scales: a synthesis of seven case studies. Fund Appl Limnol 174:1-5. doi:10.1127/1863-9135/2009/0174-0001

Scoffin TP (1993) The geological effects of hurricanes on coral-reefs and the interpretation of storm deposits. Coral Reefs 12:203-221. doi:10.1007/Bf00334480

Shaw EC, Munday PL, McNeil BI (2013) The role of $\mathrm{CO}_{2}$ variability and exposure time for biological impacts of ocean acidification. Geophys Res Lett 40:4685-4688. doi:10.1002/ Grl.50883

Stella JS, Pratchett MS, Hutchings PA, Jones GP (2011) Coralassociated invertebrates: Diversity, ecological importance and vulnerability to disturbance. Oceanogr Mar Biol 49:43-104

Teh LSL, Teh LCL, Sumaila UR (2013) A global estimate of the number of coral reef fishers. PLoS One 8:e65397. doi:10.1371/ journal.pone. 0065397

Tester PA, Feldman RL, Nau AW, Kibler SR, Litaker RW (2010) Ciguatera fish poisoning and sea surface temperatures in the Caribbean Sea and the West Indies. Toxicon 56:698-710. doi:10. 1016/j.toxicon.2010.02.026

Tewksbury JJ, Huey RB, Deutsch CA (2008) Putting the heat on tropical animals. Science 320:1296-1297. doi:10.1126/science. 1159328

Thurber RV, Burkepile DE, Correa AM, Thurber AR, Shantz AA, Welsh R, Pritchard C, Rosales S (2012) Macroalgae decrease growth and alter microbial community structure of the reefbuilding coral, Porites astreoides. Plos One 7:e44246. doi:10. 1371/journal.pone.0044246

Tobin A, Schlaff A, Tobin R, Penny A, Ayling T, Ayling A, Krause B, Welch D, Sutton S, Sawynok B, Marshall N, Marshall P, Maynard J (2010) Adapting to change: minimising uncertainty about the effects of rapidly-changing environmental conditions on the Queensland Coral Reef Fin Fish Fishery. Final Report to the Fisheries Research \& Development Corporation, Project 2008/103. James Cook University, Townsville

Vanwoesik R, Ayling AM, Mapstone B (1991) Impact of tropical cyclone Ivor on the Great-Barrier-Reef, Australia. J Coast Res 7:551-557

Walker B, Meyers JA (2004) Thresholds in ecological and socialecological systems: a developing database. Ecol Soc 9:3

Walther GR, Post E, Convey P, Menzel A, Parmesan C, Beebee TJ, Fromentin JM, Hoegh-Guldberg O, Bairlein F (2002) Ecological responses to recent climate change. Nature 416:389-395. doi:10. $1038 / 416389$ a

Webster PJ, Holland GJ, Curry JA, Chang HR (2005) Changes in tropical cyclone number, duration, and intensity in a warming environment. Science 309:1844-1846. doi:10.1126/science. 1116448

Wenger AS, Johansen JL, Jones GP (2012) Increasing suspended sediment reduces foraging, growth and condition of a planktivorous damselfish. J Exp Mar Biol Ecol 428:43-48. doi:10.1016/j. jembe.2012.06.004 
Wenger AS, McCormick MI, McLeod IM, Jones GP (2013) Suspended sediment alters predator-prey interactions between two coral reef fishes. Coral Reefs 32:369-374. doi:10.1007/ s00338-012-0991-z

Wenger AS, McCormick MI, Endo GGK, McLeod IM, Kroon FJ, Jones GP (2014) Suspended sediment prolongs larval development in a coral reef fish. J Exp Biol 217:1122-1128. doi:10. 1242/Jeb.094409

Westlund L, Poulain F, Bage H, van Anrooy R (2007) Disaster response and risk management in the fisheries sector. FAO, Rome

Westmacott S, Cesar HSJ, Pet-Soede L, Lindén O (2000) Coral bleaching in the Indian Ocean: Socio-economic assessment of effects. In: Cesar HSJ (ed) Collected essays on the economics of coral reefs. CORDIO, University of Kalmar, Kalmar

Williamson DH, Ceccarelli DM, Evans RD, Jones GP, Russ GR (2014) Habitat dynamics, marine reserve status, and the decline and recovery of coral reef fish communities. Ecol Evol $4: 337-354$
Wilson SK, Graham NAJ, Pratchett MS, Jones GP, Polunin NVC (2006) Multiple disturbances and the global degradation of coral reefs: are reef fishes at risk or resilient? Global Change Biol 12:2220-2234. doi:10.1111/j.1365-2486.2006.01252.x

Witt V, Wild C, Uthicke S (2012) Interactive climate change and runoff effects alter O-2 fluxes and bacterial community composition of coastal biofilms from the Great Barrier Reef. Aquat Microb Ecol 66:117-131. doi:10.3354/Ame01562

Woodley JD (1980) Hurricane Allen destroys Jamaican coral reefs. Nature 287:387. doi:10.1038/287387a0

Yates $\mathrm{KK}$, Halley $\mathrm{RB}$ (2006) $\mathrm{CO}_{3}{ }^{2-}$ concentration and $\mathrm{pCO}_{2}$ thresholds for calcification and dissolution on the Molokai reef flat, Hawaii. Biogeosciences 3:357-369

Young IR, Zieger S, Babanin AV (2011) Global trends in wind speed and wave height. Science 332:451-455. doi:10.1126/science. 1197219 